\title{
The sustainability of small-scale sheep farming systems in the Northern Cape (Hantam Karoo), South Africa
}

Zenda, M. ${ }^{1} \&$ Malan, P. ${ }^{2}$

Corresponding Author: M. Zenda. Mail: mashyit@yahoo.co.uk

\begin{abstract}
The objective of the study was to assess the current sustainability of small-scale sheep farming systems in the Hantam Karoo, Northern Cape Province (South Africa). The influence of economic, social, and environmental variables (indicators) in promoting the development of sustainable sheep farming was taken into account. Thirty-two small-scale sheep farmers were interviewed using questionnaires which consisted of structured and unstructured questions. The results showed that the sheep farming system was mostly not economically viable due to low sheep numbers, but partially sustainable in the social context. Small flocks result in low income and profitability which is not sustainable. Market access was not a limitation because farmers had good trade relations. Farming benefitted farmers'families and the community and farmers had access to basic resources. Secure tenure was a major challenge to small-scale farmers. With regard to environmental variables, grazing conditions were poor. In 2017, stocking density was within the norm, which means that frequent droughts and continuous grazing methods rather than sheep stocking rates were probably responsible for poor grazing conditions. Extension advisors could teach the practice of rotational grazing and it might be a good idea to promote gender equality in order to alleviate poverty and increase food security.
\end{abstract}

Key words: Small-scale sheep farmers, triple bottom-line sustainability, Hantam Karoo, veld condition

\section{INTRODUCTION}

The issue of sustainability has been the focus of many livestock farming systems. The sustainability of livestock farming systems depends on sustainability principles such as conserving natural resources, reducing risks, maintaining biological productivity, economic viability, and social acceptability (Snyman, 1998; Atanga et al., 2013). The definition of sustainability emphasises a combination of social, environmental, and economic aspects of livestock systems (Buckwell et al., 2015). The issue is being revisited now due to crises related to environment, economic viability, and social pressures (Dumanski et al., 1998; Molotsi et al., 2017).

\footnotetext{
${ }^{1} \mathrm{PhD}$ student, Centre for Sustainable Agriculture, Rural Development \& Extension Faculty of Natural and Agricultural sciences, University of the Free State, Republic of South Africa, mashyit@yahoo.co.uk

${ }^{2}$ Lecturer, Department of Animal, Wildlife and Grassland Sciences, Faculty of Natural and Agricultural sciences, University of the Free State, Republic of South Africa, +27(0)51 401 2685/2221, malanpj@ufs.ac.za
} 
In most communal lands in South Africa, there is extensive grazing of livestock, the most of which are sheep and goats (Cousins, 2008). The carrying capacity of livestock is high, but changes in response to rainfall, are causing fluctuations - with populations to decline under drought conditions or increasing under high rainfall conditions.

The rangelands are heavily overgrazed, and some dwarf Karoo bushes have been replaced by less palatable grass and bush, resulting in overgrazed and degraded land (Cousins, 2008). Soil erosion and deforestation are a major problem around settlements in the communal lands of South Africa. The reason behind this is that within grazing areas of communal spaces there is minimal management of natural resources, which subjects them to continuous grazing (McDermott et al., 2010).

There is a need, therefore for research to assess the sustainability of small-scale sheep farming to promote the development of sheep farming systems in a sustainable way. Different scholars have used different methods to assess the sustainability of livestock farming systems including the use of sustainable indicators. Sustainability indicators can be used as a method to evaluate the sustainability of farming systems (Dumanski et al., 1998; Zinck et al., 2002; Rao \& Rogers 2006; Hayati et al., 2010; Lebacq et al., 2013; Ngufor et al., 2013; Wrzaszcz \& Prandecki 2015). Such indicators differ between studies, depending on the objective of the study, farming system and its environment. Indicators such as economic, social, and environmental indicators can be used to assess the sustainability of livestock farming, using a case study approach (Lebacq et al., 2013). Under social indicators, the following parameters have been measured (internal social sustainability): working conditions, education, and quality of life of the people in the farming community. external social sustainability involves the multifunctionality and acceptability of farming practices as well as quality of agricultural produce. Social indicators can be classified into qualitative and quantitative types. Parameters such as productivity, efficiency, and farm income, are used to assess economic sustainability (Lebacq et al., 2013).

Practices on the farm such as stocking rate of livestock, and polluting emissions based on the state of the farm can be used to assess environmental sustainability. For that reason, effectbased indicators usually cover a larger area than the farm. The use of indicators on a farm is suitable because they are easy to implement, and are sensitive to farming practices (Lebacq et al., 2013). The biggest challenge when using indicators is that there is a need for transparency in their selection to avoid bias (Lebacq et al., 2013). The indicators that were developed for this study were site-specific, because they cover all social, economic, and environmental aspects of farming systems (Hayati et al., 2010; Ngufor et al., 2013). Measuring sustainability requires a higher level of observation and skills and to assess the sustainability at a farm level is a good method (Hayati et al., 2010). The use of indicators allows different farms to be compared in terms of social, economic, and environmental aspects of performance.

This paper sketches an overview of the sustainability of small-scale sheep farming systems in the Northern Cape Province of South Africa. The context is communal grazing areas close to 
human settlements. As an integral part of land reform (Aliber, 2019; Conradie, 2019) detailed data of the small-scale sheep farming systems is important in promoting the development of sheep farming systems in a sustainable way.

\section{METHODOLOGY}

\subsection{Study Area}

The Hantam Karoo falls within the Succulent Karoo Hotspot, which extends across the Western part of South Africa and a small part of Namibia. According to Van der Merwe et al. (2008) in the south, it stretches from Ceres Karoo where the Swartberg and Bontberg mountains meet, and in the north into the Tanqua basin (Figure 1).

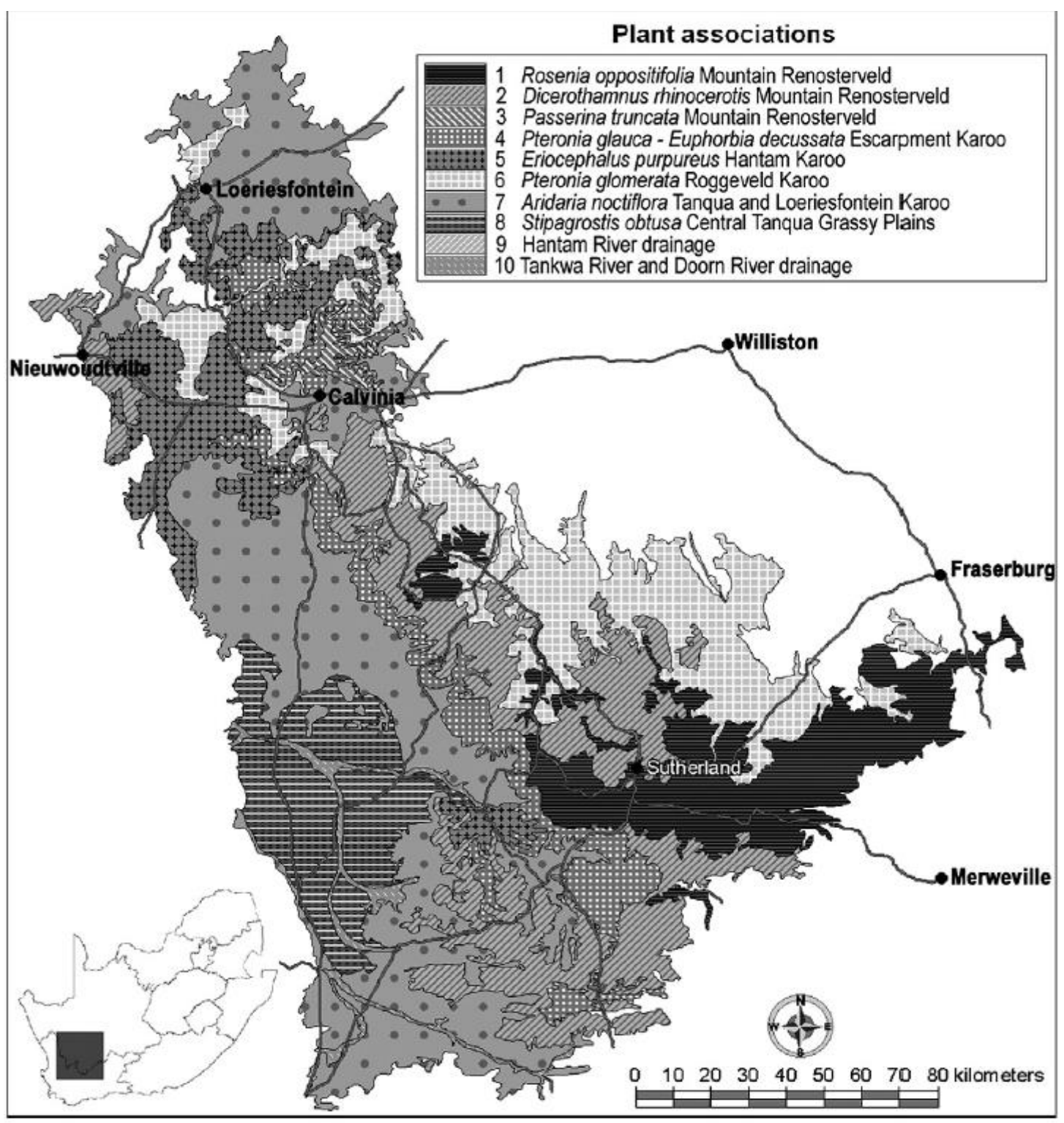

Figure 1: The eight vegetation types found in the Hantam Karoo (Van der Merwe and Van Rooyen, 2011) 
On the eastern border, it covers the Hantam, Komsberg, Klein Roggeveld and Nuweveld mountains, which lie Southwest of Fraserburg. The Cederberg and Bokkeveld mountains lie on the north side of Loeriesfontein and form the western boundary. The Hantam Karoo where the study was conducted, consists of Brandvlei, Loeriesfontein, Calvinia and Nieuwoudtville (Centre for Development Support, 2007).

The rugged slopes and cool highlands of the Hantam Karoo contain a variety of vegetation types, characteristic of transition zones between the Renosterveld and Succulent Karoo. The total area in the Hantam Karoo is 86,600 hectares. It has 357 Succulent Karoo and 173 Red listed species. The Cedarberg-Koue Bokkeveld complex is located in the Hantam area, which contains components of both the Cape Floristic region and Succulent Karoo hotspots. The main economic activity of the Succulent Karoo is livestock farming. Sheep, goat, ostrich and game ranching are the main type of livestock kept in the area, (Hantam Municipality Annual Report, 2015-2016). Rooibos tea production is also done in the area, as well as some mining activity in the Hantam, which includes salt and gypsum (Hantam Municipality Annual Report, 20152016). The Akkerendam Nature Reserve and the historical buildings attract visitors from various destinations, making the Hantam Karoo a popular destination for tourists, (Centre for Development Support, 2007).

\subsection{Data collection phase}

Within the Hantam Karoo, several variables/indicators were assessed. Under economic viability the following were assessed; alternative markets, trade relations and profits. Under social acceptance, we gathered data on family benefits, community benefits, tenure rights, and access to basic needs. Under environmental issues, the assessment covered impact of sheep stocking rate on the veld, effect of grazing methods on the veld. The economic viability, environmental issues and social acceptance were assessed using a questionnaire, consisting of structured and unstructured questions. It was appropriate to formulate the questionnaire in Afrikaans since most of the small-scale sheep farmers to be interviewed were Afrikaans speaking. The questionnaire was designed to encourage the interviewed respondents to read, understand and meaningful respond to questions. The descriptive analysis was done by using the Statistical Package for the Social Science (SPSS version 22) programme, to identify the means, modes of variables, and frequencies.

The target group was small-scale farmers involved in sheep production, on commonage land, thus land that belonged to the municipality. A stratified sampling technique was used to select 32 small-scale sheep farmers from the following areas of the Hantam Karoo: Calvinia, Loriesfontein, Nieuwoudtville and Brandvlei. Under this method, the sample frame was divided to make homogenous and non-overlapping strata and a simple random sample was drawn from each subgroup. The aim of the survey was to assess characteristics such as gender, 
age, education level, number of years in sheep farming, dependencies, and the constraints facing small-scale sheep farmers in the Hantam Karoo.

A similar study was conducted by Atkinson (2007) to examine the problem of managing commonage land being used by the emerging farmers in the Nama-Karoo commonage. This study applied the sustainable livelihoods approach to suggest that environmental knowledge is important aspect for small farmers, and that suitable approaches to agricultural extension need to be adopted to promote ecological knowledge. The aforementioned study by Atkinson have contributed immensely to the body of existing literature regarding sustainable livelihood approach. However, the major limitation of that study is that within the sustainable livelihoods approach, the issue of social, and economic knowledge has not received much attention. Social and economic knowledge are of paramount importance, they cannot be ignored, they are key assets of small-scale sheep farmers. It is a collective impact of these social, economic, and environmental knowledge that determine the failure or success of small-scale sheep farming systems. The bottom line is that these elements have to be examined together. Any alteration of one element has a systematic impact on the whole sheep farming system.

A similar study was conducted by Atkinson and Büscher, (2006) to assess the municipal commonage and implications for land reform in Philippolis, Free State province. This study is amongst those that have attempted to actively include the importance of the socio-economic aspects, views regarding land ownership, and economic ambitions of farmers involved in the use of commonage land. One limitation of that study is the aspect of environmental sustainability which is missing. Environmental sustainability cannot be ignored; it has an impact on the sustainability of farming systems. Therefore, a more comprehensive analysis is needed, including social, economic and environmental aspects of sheep farming systems, to meet sustainability goals, and to enhance food security and poverty reduction.

This study was aimed to, amongst others, address the possible gap existing in literature, by assessing the sustainability of small-scale sheep farming systems giving precise attention to social, economic and environmental aspects of sustainability. This was conducted at community level, incorporated together, and then examined as a single item, to see the implications thereof.

A conceptual model of sustainability was used in data analysis. This concept promotes the expansion of sheep farming systems to occur in a way that meets the need of the present generation, without compromising the ability of the next generation to meet their own needs and consists of three pillars, namely economic, environmental and social sustainability. For a sheep farming system to be sustainable, the social, economic, and environmental components have to be in balance and minimum criteria need to be met. If one of the components is absent the system cannot be sustainable. 


\section{RESULTS AND DISCUSSION}

\subsection{Demographic information}

\subsubsection{Respondents' gender distribution}

The results of the survey (see Table 1) show that small-scale sheep farmers in the Hantam Karoo are predominantly men $(78 \%)$, whilst only $22 \%$ were women. Kongolo \& Dlamini (2012) found similar results that more men than women owned livestock in small-scale farming systems. This revealed a gender gap and that any strategy for the development of small-scale farming systems in the area would unequally benefit men and women. Gender balance is important for full utilisation of potentials of women and men in small-scale farming systems (Fao, 1998). Atanga et al. (2013) found that women are often excluded in making decisions and in controlling resources in households. It might be a good idea to promote gender equality in order to alleviate poverty and increase food security.

Table 1 Summary Statistics of a survey carried out in Hantam Karoo $(n=32)$

\begin{tabular}{|l|l|}
\hline Gender distribution & Percentage \\
\hline Men & 78 \\
\hline Women & 22 \\
\hline Age (Years) & 3 \\
\hline $26-30$ & 0 \\
\hline $31-35$ & 3 \\
\hline $36-40$ & 6 \\
\hline $41-50$ & 22 \\
\hline 61 and over & 32 \\
\hline Education Level & Percentage \\
\hline No schooling & 13 \\
\hline Grade R to 8 & 50 \\
\hline Grade 9 to 12 & 19 \\
\hline Matriculated & 6 \\
\hline Tertiary qualification e.g. Diploma, degree & 12 \\
\hline Farming experience & Percentage \\
\hline Less than 5 years & 41 \\
\hline 5 to 10 years & 31 \\
\hline 10 to 20 years & 19 \\
\hline Less than 20 years & 9 \\
\hline Reasons for not being economically viable & Percentage \\
\hline Insufficient income generation & 91 \\
\hline Low sheep numbers & 91 \\
\hline Struggle to sell sheep & 3 \\
\hline Insufficient lamb production & 34 \\
\hline Tenure rights & Percentage \\
\hline
\end{tabular}




\begin{tabular}{|l|l|}
\hline Yes & 16 \\
\hline No & 84 \\
\hline Monthly income level & Percentage \\
\hline $0-500$ & 62 \\
\hline $501-1000$ & 16 \\
\hline $1001-2000$ & 6 \\
\hline $2001-3000$ & 3 \\
\hline $5000+$ & 13 \\
\hline Profit & Percentage \\
\hline Yes & 31 \\
\hline No & 69 \\
\hline Trade relations & Percentage \\
\hline Good & 78 \\
\hline Bad & 22 \\
\hline Benefiting from farm & Percentage \\
\hline Family & 81 \\
\hline Community & 59 \\
\hline Access to basic needs & Percentage \\
\hline Yes & 81 \\
\hline No & 19 \\
\hline
\end{tabular}

\subsubsection{Respondents' ages}

The study revealed that only $6 \%$ of the respondents were younger than 35 years, with the most being 61 years and older (Table 1). This indicated that young adults were not interested in small-scale sheep farming, which could compromise sustainability and continuity in the community. This agrees with the results of Swarts \& Aliber (2013) who reported that the challenge to attract the youth in agriculture is greater in the rangeland commons of South Africa.

\subsubsection{Respondents' level of education}

The respondents' level of education varied widely (Table 1). Half the respondents went to school from grade R to Grade 8 and 19\% went from grade 9 to 12 . This indicated that the level of literacy of respondents was reasonable and that the level of education was sufficient to allow interpretation and understanding of the basic sustainable sheep farming practices and principles.

\subsubsection{Respondents' number of years in farming experience}

The results in Table 1 show the number of years in which the respondents were involved in sheep farming. About $41 \%$ had less than 5 years in farming, while $59 \%$ had more than five years of experience. 


\subsection{Indicators to assess respondents' farming sustainability}

Under this section, indicators were used to assess the sustainability of small-scale sheep farming systems in the Hantam Karoo. The three pillars of sustainability, namely economic, environmental and social indicators, were used.

\subsubsection{Economic viability}

Economic viability of small-scale sheep farmers is important to maintain farming operations from one season to the next. The first step in farming performance is the technical or reproductive efficiency of the system, which is extensive grazing in areas such as the Hantam and is largely dictated byrangeland condition. Mature body weight, reproductive rate, and fibre production are the major factors that determine the profitability of sheep enterprise (Snyman \& Herselman, 2005). In addition to rangeland condition, the condition of sheep could be improved by intensive inoculation, deworming, dipping or extra feeding (D'haese et al., 2001). This might enhance the quality, production, and selling price of sheep, resulting in a higher cash flow.

The farming system becomes economically viable if it is of sufficient technical efficiency to yield a positive gross margin under prevailing input and output prices. A positive gross margin will result in a positive net farm income (= profitable). The gross margin analysis involves the estimated income and directly allocatable variable costs of an enterprise on a per-unit basis per stock unit, or per hectare (Standard bank, 2013). However, these costs are often expressed per enterprise, per hectare or per stock unit basis, the most relevant measure is the cost per unit of output (Morris, 2009). A profitable small-scale farm might contribute to household income or not, depending on the dependency ratio of the household and other job opportunities in the immediate area. If the net balance stays positive, we get acceptable livelihoods.

In this atudy, $91 \%$ of the respondents indicated that their incomes were not enough to sustain their families (Table 1). Van der Merwe et al. (2008) found similar results in the Hantam Karoo with low income from farming, because of unfavourable and harsh conditions in the area. This indicates that the small-scale sheep farmers in the Hantam Karoo were not generating profits in the short and long-term. Therefore, extension advisers need to address the issue of economic viability of small-scale farming systems in the Hantam Karoo.

The reasons respondents gave why sheep farming systems were not economically viable are shown in Table one. Most respondents (91\%) indicated that their economic viability were limited by flock size. Approximately a third of respondents (34\%) cited low reproductive rates as a reason. McDermott et al. (2010) and Molotsi et al. (2017) reported that poor animal husbandry practices of small-scale livestock farmers are associated with low birth rates, and high mortality rates. In the case of the Hantam, these poor birth rates could rather be the result 
of extremely harsh environmental conditions, duae to unreliable rainfall and therefore poor rangeland conditions. A recent analysis has shown that farm efficiency is undermined by rising temperatures and lower than normal rainfall (Conradie et al., in press), central elements of the climate change forecast for the arid western half of South Africa (Water Research Commission and South African Weather Service, 2017).

Generating income is important for sustainable sheep farming systems. Only 3\% of respondents struggled to sell their sheep, indicating that marketing or selling of sheep is not an issue that extension advisers need to address (Table 1). Income levels from farming activities showed that $62 \%$ of the respondents earned between R0 to R500 per month while $16 \%$ earned between R501 to R5000+ per month (Table 1). These results indicate that the levels of income from the farming activity per month was very low, meaning that they are not generating sufficient income for the farming system to be economically viable. These results undermine the economic viability aspect of sustainability.

Making a profit is a key element to enhance the economic viability of small-scale sheep farming systems. The results of this study showed that only $31 \%$ of the respondents were making a profit from the sheep farming system (Table 1). Thus, small-scale sheep farming systems were not economically viable for all farmers and is an issue that needs to be addressed. The farmer should be able to prosper and sustain investment while providing consumers with quality affordable food (Buckwell et al., 2015).

Fair trade practices are important for sustainable sheep farming systems, it allows farmers to have access to the markets where fair prices can be negotiated. Fair trading practices include legal rights, which allow farmers to have access to markets where fair prices can be negotiated (Gayatri et al., 2016). In this study, 78\% of the respondents indicated that they had adequate market access (Table 1). This indicate that fair trading practices is not an issue that extension advisers need to address.

\subsubsection{Social viability}

Sheep farming systems has several social functions, both at the level of the farming community, and at the level of society. The definition of these functions depends on present day societal values and concerns. The farming system have to be organised in such a way that social conditions are optimal for the people who work there (Van Cauwenbergh et al., 2007). This refers to family benefits, and community benefits from the farming systems such as gender, equality, and access to basic resources (Van Cauwenbergh et al., 2007). Family benefits, and community benefits from the faming systems can reflect social equality. Therefore, there should be no large gap between sheep farmers regarding access to basic resources and equality. Having access and equality to basic resources can ensure social stability and can encourage small-scale farmers to improve production, while conserving resources (Zhen and Routray, 2003). 
Social viability of small-scale sheep farming systems is important to enhance sustainability thereof. The results of this study showed that $81 \%$ of the respondents' families benefitted from the farming system (Table 1). Furthermore, 59\% of the respondents benefitted the community. Atkinson \& Igle (2018) found similar results that commonage users in the karoo towns of Carnavon and Willston in the Northern Cape Province were employing some herdsmen to do farm work, thereby creating incomes for other families. Atkinson (2013) reached a similar conclusion that many commonage farmers sometimes employ herders, thus creating jobs to the local people. Therefore, the social viability with regard to family and community benefits is not an issue the extension advisers need to address.

Land tenure is important to enhance sustainable sheep farming systems. It determines the sustainability of small-scale sheep farming systems. When the ownership of land is mostly communal, there would be little incentives to practice sustainable land management efficiently. The results of this study revealed that $84 \%$ of the respondents did not have tenure rights (Table 1). Land tenure is an issue in Southern Africa, and a pragmatic review is crucial if future sustainable utilization of natural resources is to be achieved (Kadzere, 1996). Atkinson \& Igle (2018) reported the following problems with communal tenure in the commonages of South Africa. Firstly, the South African government was never engaged with commonage land as a new institutional form. This was because municipalities, before 1994, had lost their practical competence to manage agricultural land and municipalities' role was limited to supervising infrastructure and collecting rentals. A similar observation was noted by Atkinson (2013) that the South African government is not committed to manage land tenure. Secondly, after 1994, neither land reform nor agriculture was regarded as municipal functions, in terms of the constitution of South Africa. Thus, the central government did little to orient municipalities to manage commonage land effectively. It was left to the Provincial Department of Agriculture to assist new farmers involved in commonage land. However, the Department of Agriculture are not the owners of commonage land, and so they depend on the positive interest and competence of municipalities in commonage management, and this is lacking. Atkinson (2013) reported that there is poor track record of collective farms under the land redistribution. This shows how difficult such management systems are. With effective institutions, some version of land tenure may work well. Furthermore, Atkinson (2013) reported that there is no coherent national framework on the allocation of commonage land. There is no effective guidance on land management systems from the provincial departments of co-operative governance. Lastly, the administrative and political upheavals undermine commonage farming aspects, as it prevents transparent, effective and fair systems of access use of commonage land (Atkinson, 2013). This indicates that extension advisers need to address the issue of land tenure.

Access to basic resources is important for the sustainability of sheep farming systems. It is important that basic resources should be accessible to all community members who participate in food security, for sustainable farming systems. The results of this study revealed that $81 \%$ of the respondents had access to basic resources (Table 1). This indicated that access to basic 
resources was not an issue that extension advisers needed to address. It can be concluded that the social dimension of the sheep farming system was partially sustainable.

\subsubsection{Environmentally viability}

Environmental viability of small-scale sheep farming systems is important in protecting and conserving natural resources such as veld and pastures. According to Hoffman \& Todd (2000) the rate of veld degradation is higher in the communal areas than in the commercial areas. The high stocking rates on the communal rangelands has clearly impacted negatively on the vegetation (Todd \& Hoffman, 1999). A similar observation was noted by Todd \& Hoffman (2000) that the high stocking rates in the communal areas of the Namaqualand Karoo had a definite negative impact on the vegetation resulting in veld degradation. Veld degradation is caused by overgrazing, due to over stocking. In the Karoo, overgrazing can have serious consequences, for instance thinning of vegetation caused by grazing can result in increased runoff, high soil temperatures, increased soil moisture evaporation and increased soil erosion (Atkinson, 2007). Atkinson (2007) further reported that in the Karoo, where the ecosystem can be easily disturbed by overgrazing, it is of paramount importance that commonage farming systems be conducted with extensive knowledge of veld maintenance, for sustainable livelihoods to be created. This study showed that $59 \%$ of the respondents believed that the current veld condition was average while $41 \%$ felt it was poor (Table 2 ). The stocking density was within the norm, which means that frequent droughts could have contributing to the veld condition not being favourable. This indicates that the veld condition is a challenge that extension advisers need to address, by creating awareness amongst the farmers on how to manage drought situation.

Table 2 Response of participants to environmental related questions $(n=32)$

\begin{tabular}{|l|c|}
\hline Veld condition & Percentage \\
\hline Poor & 41 \\
\hline Average & 59 \\
\hline Excellent & 0 \\
\hline Drought & \\
\hline Yes & 91 \\
\hline No & 9 \\
\hline Grazing practice & \\
\hline Rotation & 44 \\
\hline Continuous & 56 \\
\hline Overstocking & \\
\hline Yes & 31 \\
\hline No & 69 \\
\hline
\end{tabular}


Drought is of major concern for the environmental viability of small-scale sheep farming systems especially the Hantam Karoo, a low rainfall region. The results showed that, $91 \%$ of the respondents were facing the challenge of drought (Table 2). Jordaan et al. (2013) proved that drought occur regularly in the Northern Cape Province. Drought can reduce perennial plant cover, which in turn reduce the number of livestock the veld can support. Droughts also have a large negative effect on veld recovery (Todd et al., 2009). This indicates that extension advisers should train farmers how to respond to drought in order to prevent rangeland deterioration.

The other reason for the veld condition being unsatisfactory may be continuous grazing practices of small-scale sheep farmers in the study area. Continuous grazing may have a negative impact on the veld condition. The study revealed that $56 \%$ of respondents used continuous grazing while $44 \%$ rotated their sheep in their paddocks (Table 2). McDermott et al. (2010) found similar results that within communal grazing areas there is minimal management of natural resources, due to continuous grazing. Todd et al. (2009) added that continuous grazing is common in communal areas of the Namakwa district of Northern Cape Province, South Africa. Todd \& Hoffman (1999) also reported that management of communal rangelands are associated with continuous grazing, while the commercial rangelands are rotationally grazed. This is a clear indication that the veld is not threatened by drought only, but also by limited rotation of sheep in paddocks. Atkinson \& Igle (2018) reported that in the Karoo towns of Carnavon and Willston in the Northern Cape Province, poor grazing conditions is a factor that is encouraging commonage farmers to leave their municipal land.

Stocking rate of livestock is important in the sustainability of farming systems. Stocking rates influences animal performance through restricting the amount of feed available to each animal, or by limiting their choice of the more nutritious pasture components (Wilson and Macleod, 1991). This study revealed that most respondents (69\%) felt that there were not too many sheep in the veld. This showed that stocking rate might not be a major issue to be addressed in order to promote the development of sheep farming systems in a sustainable way. These results agree with Allsop et al. (2007) who found that the carrying capacity of livestock in Northern Cape Province was not considered to be a fixed parameter, but rather as a variable dependent on rainfall. Cousins (2008) further reported that in most communal areas there are high stocking rates, but responds to rainfall with populations declining in drought years and bouncing back in years of high rainfall. Both Todd et al. (2009) and Cloete et al. (2014) found similar results where environmental constraints in South African rangelands have resulted in poor production environments with low carrying capacity in most areas. It can be concluded that the environmental dimension of the sheep farming system is, to a large extent, not sustainable.

\section{CONCLUSION AND RECOMMENDATIONS}

The objective of this study was to assess the economic viability, social acceptance, and environmental viability of small-scale sheep farming systems in the Hantam Karoo, Northern 
Cape Province of South Africa. From the data, we found that the sheep farming system was not economically viable, to a large extent, but on the social dimension, it was partially sustainable. The environmental dimension of the sheep farming system was mostly not sustainable. We noted that under economic viability, the income of respondents was not enough to sustain their families. Furthermore, respondents indicated they were not economically viable due to low sheep numbers. Low levels of income per month and low profits were noticed. The respondents did not struggle to market their sheep, which may have contributed to the economic development of the area.

It was also found that on the social dimension of the sheep farming system, the respondents' sheep farming systems benefitted their families and community, and that they had access to basic needs. Insecure tenure rights to own/lease land was a major challenge facing the respondents. Under environmental viability, the veld condition was not ideal for sustainable sheep production. High sheep stocking rates might not have been responsible for poor veld conditions, but rather frequent drought conditions and continuous grazing.

Continuous grazing destroys veld condition, it is therefore suggested that the extension advisers should guide small-scale sheep farmers to apply rotational grazing practices. It raises a question about whether the small-scale sheep farmers are managing their veld in the Hantam Karoo effectively. Extension advisers should also advise small-scale sheep farmers to strategically give supplement feeding during droughts and winter seasons to maintain the condition of sheep.

There is a need for involvement of various stakeholders, such as non-governmental organisations, the private sector and the Department of Agriculture to promote sheep farming while taking social acceptability, economic viability and environmental viability into account. The social, economic and environmental aspects of sustainability have to be in balance. If one aspect is absent, there is need for immediate intervention. Extension advisers should implement a training program to help small-scale sheep farmers to apply sustainable agricultural practices. Such training programs should be monitored and evaluated to ensure the achievement of the goals of sustainable development. Through the data presented, extension advisers can measure trends and progress towards meeting sustainability goals. Additionally, this will lead to more sustainable sheep farming systems to enhance food security and poverty reduction.

\section{REFERENCES}

ALIBER, M. 2019. How we can promote a range of livelihood opportunities through land redistribution. Working paper 58, Programme for Land and Agrarian Studies, University of the Western Cape, South Africa

ALLSOP, N., LAURENT, C., DEBEAUDOIN, L.M.C. \& SAMUELS, I.S. 2007. Environmental perceptions and practices of livestock keepers on the Namaqualand Commons challenge conventional rangeland management. Journal of Arid Environments, 70:740-754 
ATANGA, N.L., TREYDTE, A.C. \& BIRNER, R. 2013. Assessing the Sustainability of Different Small-Scale Livestock Production Systems in the Afar Region, Ethiopia. Land. 2:726-755

ATKINSON, D. 2007. People-centred environmental management and municipal commonage in the Nama Karoo. Development Southern Africa, 24(5):707-724

ATKINSON, D. 2013. Municipal commonage in South Africa: A critique of artificial dichotomies in policy debates on agriculture, African Journal of Range and Forage Science, 30:1-2, 29-34

ATKINSON, D., \& BüSCHER, B. 2006. Municipal commonage and implications for land reform: A profile of commonage users in Philippolis, Free State, South Africa. Agrekon, 45(4):437-466

ATKINSON, D., \& IGLE, M. 2018. By their own bootstraps: Municipal commonage farmers as an emerging agrarian class in the Karoo, African Journal of Range and Forange Science, 35:3-4, 233-243

BUCKWELL, A., CAPODIECI, L.G., DE GRAEFF, R., DIJJHUIZEN, A., FRABETTI, E., LARGE, A., REYNOLDS, C., ROSATI, A., SCHOLTEN M., SCHREIBER, R., TICE, G., VERDONK, D., WILLIAMS, A., KANLI, A., \& CHAVEZ, M. (2015). Sustainable livestock production in Europe: A question of food security, climate and innovation

CENTRE FOR DEVELOPMENT SUPPORT. 2007. Arid Areas Report, Volume 1: District socio-economic profile and development plans. CDS Research Report, Arid Areas. Bloemfontein; University of Free State. 1:1-87

CONRADIE, B. 2019. Land use and redistribution in the arid west: The case of Laingsburg Magisterial district, Agrekon, 58. (3):281-291

CONRADIE, B., PIESSE, J., \& STEPHENS, J. 2019. The changing environment: Efficiency, vulnerability and changes in land use in the South African Karoo, 2012-2014. Environmental Development, 32(2019):1-12

COUSINS, B. 2008. Livestock production and common property struggles in South Africa's agrarian reform. The journal of Peasant studies, 23(2):166-208

CLOETE, S, W, P., OLIVIER, J, J, SANDENBERGH, L \& SNYMAN, M, A. 2014. The adaption of the South Africa sheep industry to new trends in animal breeding and genetics: A review. South African Journal of Animal Science, 44(4):307-321

D'HAESE, M, D., CALUS, M., KIRSTEN, J, F., VAN HUYLENBROECK, G., \& BOSTYN, F. 2001. Efficiency Analysis of small-scale wool production in the Former Transkel South Africa, Agrekon, 40(4):641-655 
DUMANSKI, J., TERRY, E., BYERLEE, D., \& PIERI, C. 1998. Performance indicators for sustainable Agriculture. Discussion note. Rural Development Sector. The World Bank. Washington, D.C.

FAO (FOOD AND AGRICULTURAL ORGANISATION). Government Cooperative Programme (1998). Improving Information on Women's Contributions to Agricultural Production for Gender Sensitive Planning. Project Findings and Recommendations; FAO: Rome, Italy. 1-10

GAYATRI, S., TORTOJADA, V, G, \& VAARST, M. 2016. Assessing sustainability of smallholder beef cattle farming in Indonesia: A case study using FAO SAFA Framework. Journal of Sustainable Development, 9. (3): Department for Animal science. Aarhus University. Denmark

HANTAM MUNICIPALITY ANNUAL REPORT. 2015-2016. Republic of South Africa

HAYATI, D., RANJBAR, Z., \& KARAMI, E. 2010. Measuring agricultural sustainability Lichtfouse (Ed) Biodiversity, biofuels, Agroforestry and conservation agriculture. Sustainable Agriculture reviews. 5:73-100

HOFFMAN, T, M., \& TODD, S. 2000. A National Review of Land Degradation in South Africa: The influence of biophysical and socio-economic factors, Journal of Southern African Studies, 26(4):743-758

JORDAN, A, J., SAKULSKI, D \& JORDAN, A, D. 2013. Interdisciplinary drought risk assessment for agriculture: The case of communal farmers in the Northern Cape Province, South Africa. South African Journal of Agriculture extension, 41:44-58

KADZERE, C, T. (1996). Animal Production Level-A Measure of Social Development in Southern Africa. Journal of Social Development in Africa. 11(1):17-31

KONGOLO, M. \& DLAMINI, D, K. 2012. Small-scale livestock farming in developing areas of Swaziland and South Africa. AFRREV STECH. An International Journal of Science and Technology, Bahir Dar, Ethiopia.1 (3):100-111

LEBACQ, T., PHILIPPE, V., BARET, V., \& STILMANT, D. 2013. Sustainability indicators for livestock farming. A review. Agronomy. Sustainable. Development. 33:311-327

MCDERMOTT, J. J., STAAL, H.A., FREEMAN, M., HERRERO, M, \& VAN DER STEEG, J.A. 2010. Sustaining Intensification of smallholder livestock systems in the Tropics. Livestock Science, 130(1-3):95-109

MOLOTSI, A., DUBE, B., OOSTING, S., MARANDURE, T., MAPIYE, C., CLOETE, S., \& DZAMA, K. 2017. Genetic traits of relevance to sustainability of smallholder sheep farming systems in South Africa. Sustainability review. 9(1225):1-18

MORRIS, S, T. 2009. Economics of sheep production. Small ruminant research, 86(2009):5962. 
NGUFOR, L, A., TREYDTE, A, C, BIRNER, R. 2013. Assessing the sustainability of different small- scale livestock production systems in the Afar Region, Ethiopia. Land, 2:726-755

RAO, N. H. \& Rogers, P.P. 2006. Assessment of Agricultural Sustainability. Current Science, 91(4):439-448

SNYMAN, H.A. 1998. Literature review. Dynamics and sustainable utilization of rangeland ecosystems in arid and semi-arid climates of Southern Africa. 39:645-666

SNYMAN, M, A. and HERSELMAN, M, J. 2005. Comparison of productive and reproductive efficiency of Afrino, Dorper and Merino sheep in the False Upper Karoo, South African Journal of Animal Science, 35(2):98-108

STANDARD BANK. 2013. Finance and Farm Management. Fifth edition. Standard bank Agribusiness SA. Johannesburg

SWARTS, M. \& ALIBER, M. 2013. The 'youth and agriculture' problem: Implications for rangeland development. African Journal of Range and Forage Science, 30(1-2): 23-27

TODD, S, W. \& HOFFMAN, M, T. 1999. A fence-line contrast reveals effects of heavy grazing on plant diversity and community composition in Namaqualand, South Africa. Plant Ecology, 142:169-178

TODD, S., MILTON, S., DEAN, R., CARRICK, P., \& MEYER, A. 2009. Ecological BestPractice Livestock Production Guidelines for the Namakwa District. Draft 1. 6-58

VAN CAUWENBERGH, N., BIALA, K., BIELDERS, C., BROUCKAERT, V., FRANCHOIS, L., GARCIA CIDAD, V., HERMY, M., MATHIJS, E., MUYS, B., REIJNDERS, J., SAUVENIER, X., VALCKX, J., VANCLOOSTER, M., VAN DER VEKEN., WAUTERS, E., PEETERS, A. 2007. SAFE-A hierarchical framework for assessing the sustainability of agricultural systems. Agriculture, Ecosystems and Environment, 120:229-242

VAN DER MERWE, H., VAN ROOYEN, M. W \& VAN ROOYEN, N. 2008. Vegetation of the Hantam-Tangua-Roggeveld Subregion, South Africa. Part 2: Succulent Karoo Biome Related Vegetation. Department of Plant Science. 50(1)160-183

VAN DER MERWE, H., and VAN ROOYEN. M, W. 2011. Life form spectra in the HantamTangua-Roggeveld, South Africa. South African Journal of Botany, 77(2011):371-380

WATER RESEARCH COMMISSION AND SOUTH AFRICAN WEATHER SERVICE. 2017. A climate change reference atlas based on CMIP5-CORDEX downscaling

WILSON, A, D., and MACLEOD, N, D. 1991. Overgrazing: Present or absent? Journal of Range Management, 44(5):475-482

WRZASZCZ, W, \& PRANDECKI, K. 2015. Assessment of agricultural sustainability. Current science, 91:4 
S. Afr. J. Agric. Ext.

Zenda, Malan

Vol. 49 No. 1, 2021: 105-121

http://dx.doi.org/10.17159/2413-3221/2021/v49n1a10781

(License: CC BY 4.0)

ZHEN, L \& ROUTRAY, J, K. 2003. Operational indicators for measuring agricultural sustainability in developing countries. Environmental management, 32(1):34-46

ZINCK, J, A, BERROTERAN, J, L, FARSHAD, A, MOAMENI, A, WOKUBI, A. \& VAN RANST, E. 2002. Approaches to assessing sustainable Agriculture. Ciencia del su. 20(2):55-68 